\title{
PENGARUH PEMBERIAN MIKROKAPSUL MINYAK IKAN TERHADAP LEMAK ABDOMEN DAN KADAR KOLESTEROL DAGING BROILER
}

\author{
Toni Malvin' ${ }^{1)}$, Mirzah $^{2)}$ dan Montesqrit ${ }^{2)}$
}

\begin{abstract}
This study was to determine the use of fish oil microcapsules in rations on the percentage of abdominal fat and cholesterol levels in broiler meat. The study used 100 DOC broilers with CP 707 code. The rations used consisted of rice bran, milled corn, soybean meal, fish meal, coconut oil, fish oil microcapsules (MMI), topmix and dolomite containing $22 \%$ protein with an energy content of $3000 \mathrm{Kcal} / \mathrm{kg}$. The research method used Completely Randomized Design (CRD) with 4 treatments and 5 replications. The first treatment $(R 1)$ is containing $0.8 \%$ fish oil (control), the second treatment $(R 2)$ contains MMI 2\%, the third treatment (R3) containing MMI 4\%, and the fourth treatment (R4) containing 6\% MMI. The parameters measured were the percentage of abdominal fat (\%) and meat cholesterol ( $\mathrm{mg} / 100 \mathrm{~g})$. The results of the analysis of variance that showed not significant effect for abdominal fat percentage until the use of MMI is 6\%. As for meat cholesterol content, R2 and R3 treatment showed a very significant different effect $(P<0.01)$ lower than $R 1$ treatment (control), and $R 4$ treatment showed significant differences $(P<0.05)$ lower than $R 1$ treatment (control), while between treatments $R 2, R 3$ and $R 4$ showed no significant effect $(P>0.05)$. Based on the results of this study, it can be concluded that the use of MMI (fish oil microcapsules) at a level of $2 \%$ in broiler rations can have a significantly different effect on meat cholesterol content than controls, whereas for abdominal fat percentage the effect is not significant until the use of MMI is 6\%.
\end{abstract}

Keywords: broiler, chicken, cholesterol, fish oil microcapsules

\section{PENDAHULUAN}

Di Indonesia, bahan pangan hewani yang tergolong murah dan ketersediaannya cukup melimpah adalah daging ayam (broiler), karena ternak broiler dapat dijadikan sebagai sarana dalam pemenuhan kebutuhan protein bagi masyarakat dalam waktu yang sangat singkat. Di daerah Payakumbuh dan Kabupaten Limapuluh Kota, ternak broiler saat ini dapat dipanen pada usia 18 hari dengan rata-rata bobot badan mencapai 8-9 ons yang istilah pasarnya adalah ayam potong empat, dimana 1 ekor ayam tersebut dipotong menjadi 4 bagian.

Peningkatan jumlah penduduk Indonesia setiap tahunnya memberikan tantangan yang penting bagi para pelaku usaha peternakan, apalagi peningkatan tersebut diiringi juga dengan naiknya pendapatan dan kesadaran masyarakat akan manfaat gizi bagi kehidupan manusia. Akibatnya, konsumsi masyarakat mulai bergeser dari bahan pangan nabati ke bahan pangan hewani, karena bahan pangan hewani mengandung protein yang tersusun dari asam amino essensial, dimana asam amino tersebut tidak dapat dibuat oleh tubuh atau pun diperoleh dari sumber makanan asal tumbuhan seperti biji-bijian, sayur-sayuran dan buah-buahan (protein nabati).

Seiring dengan hal tersebut, pemahaman kesehatan dan keamanan pangan di masyarakat juga ikut berkembang. Saat ini masyarakat sudah mulai mencari bahan-bahan pangan yang sehat, berkualitas dan berbasis organik agar kesehatan selalu terjaga dan terhindar dari kolesterol jahat dan residu-residu kimia. Disisi lain, ternak broiler dan ayam

1) Staf Pengajar Politeknik Pertanian Negeri Payakumbuh

2) Staf Pengajar Fakultas Peternakan Universitas Andalas, Padang 
petelur mengandung kolesterol yang cukup tinggi dalam daging dan telurnya, sehingga konsumen yang terkena resiko penyakit atherosclerosis (penyumbatan pembuluh darah) justru membatasi mengkonsumsi produk asal ayam. Kandungan tersebut bisa mencapai $200 \mathrm{mg}$ per $100 \mathrm{~g}$ atau bahkan lebih, dibandingkan dengan ayam kampung yang kandungan kolesterolnya lebih rendah, hanya 100-120 mg (Yusniar dan Nilasari, 2007).

Untuk memperoleh bahan pangan asal ternak ayam yang sehat dan berkualitas, perlu dilakukan usaha untuk menurunkan kandungan kolesterol dalam daging ataupun telurnya. Secara umum, kelebihan kadar kolesterol dalam daging dapat diturunkan dengan cara mengurangi konsumsi kolesterol pada pakan dan meningkatkan jumlah konsumsi asam lemak tak jenuh yang berikatan rangkap lebih dari satu, sehingga ada kecenderungan bahwa meningkatnya konsentrasi kolesterol dalam ransum juga akan meningkatkan kadar kolesterol dalam daging ayam. Berkaitan dengan itu, salah satu jalan yang dapat ditempuh untuk menghasilkan daging rendah kolesterol adalah dengan cara pemberian minyak ikan ke dalam pakan.

Pemberian minyak ikan ke dalam pakan dapat menghasilkan produk ternak yang tinggi kandungan asam lemak omega-3, karena minyak ikan mengandung asam lemak omega-3. Pemberian minyak ikan secara langsung ke dalam pakan mengalami beberapa kendala, yaitu tidak homogennya pencampuran minyak ikan di dalam ransum karena sering terjadinya penggumpalan. Disamping itu, minyak ikan dalam bentuk cair sulit penanganannya, terutama dalam hal pendistribusian dan penyimpanan, karena minyak ikan tersebut sangat mudah teroksidasi, sehingga perlu dicari upaya untuk mengatasinya. Langkah yang dapat ditempuh untuk mengatasi hal tersebut adalah dengan cara pemberian minyak ikan dalam bentuk mikrokapsul.

Mikrokapsul minyak ikan diperoleh dengan cara memerangkap minyak ikan dengan bahan penyalut dan selanjutnya dikeringkan dengan pengering semprot. Proses tersebut disebut juga dengan mikroenkapsulasi. Hasil dari mikroenkapsulasi minyak ikan tersebut diperoleh mikrokapsul minyak ikan yang berbentuk tepung dengan kandungan ME dan protein kasar masing-masing sebesar 3691 Kkal dan 31,50\% (Montesqrit dan Adrizal, 2007). Pemberian minyak ikan dalam bentuk mikrokapsul belum banyak dilaporkan, sehingga perlu dilakukan penelitian untuk mengetahui bagaimana pengaruh pemberian mikrokapsul minyak ikan terhadap lemak abdomen dan kadar kolesterol daging broiler.

\section{MATERI DAN METODA}

Ternak percobaan yang digunakan adalah 100 ekor DOC broiler kelamin jantan dan betina (unsex) umur 2 (dua) hari dengan kode CP 707. Ransum yang digunakan adalah ransum yang diaduk sendiri dengan kadar protein sekitar $22 \%$ dengan kandungan energi sekitar 3000 $\mathrm{Kkal} / \mathrm{kg}$. Bahan-bahan ransum terdiri dari jagung giling, dedak halus, tepung ikan, bungkil kedelai, minyak kelapa, mikrokapsul minyak ikan, topmix dan tepung batu (dolomit). Minyak ikan diperoleh dari hasil sampingan pengolahan tepung ikan dari Muncar, Banyuwangi. Bahan penyalut untuk pembuatan mikrokapsul minyak ikan adalah tepung daging dan bungkil kelapa dengan perbandingan $77 \%$ dan $23 \%$ (Montesqrit dan Adrizal, 2009). Komposisi dan kandungan zat makanan yang digunakan dalam penelitian ini dapat dilihat pada Tabel 1 dan Tabel 2. 
Kandang yang digunakan adalah kandang panggung yang diberi alas litter (sekam padi) dan disekat-sekat sebanyak 20 unit dengan ukuran perunit $0.5 \mathrm{~m} \mathrm{x} 1$ $\mathrm{m}$. Setiap unit kandang dilengkapi dengan 1 buah tempat makan dan minum, serta lampu pijar 60 Watt untuk alat pemanas dan penerang.

Metode penelitian ini menggunakan Rancangan Acak Lengkap (RAL) dengan 4 perlakuan dan 5 ulangan. Perlakuan adalah pemberian Mikrokapsul Minyak Ikan (MMI) yang terdiri dari: Perlakuan 1 (R1) mengandung minyak ikan $0,8 \%$ (kontrol), perlakuan 2 (R2) mengandung MMI 2\%, perlakuan 3 (R3) mengandung MMI $4 \%$ dan perlakuan 4 (R4) mengandung MMI 6\%.

Model matematika dan rancangan yang digunakan adalah : $\mathrm{Yij}=\mathrm{u}+\mathrm{Ti}+€ \mathrm{ij}$ Keterangan $:$ Yij $=$ Hasil pengamatan pada perlakuan ke-i dan ulangan ke-j $\mathrm{u}=$ Nilai tengah umum $\mathrm{Ti}=$ Pengaruh perlakuan ke$\mathrm{i} €=$ Pengaruh sisa (acak) ke-j yang mendapat perlakuan ke-i. Untuk mengetahui pengaruh perlakuan, semua data dianalisa dengan analisis statistik menggunakan sidik ragam, dan dilanjutkan dengan uji lanjut DMRT bila ada perbedaan nyata antar perlakuan (Steel dan Torrie, 1995).

Untuk pembuatan 100 gram mikrokapsul minyak ikan dibutuhkan bahan penyalut 80 gram (63 gram tepung daging + 17 gram bungkil kelapa), selanjutnya bahan-bahan tersebut dilarutkan dalam air. Imbangan minyak ikan dengan penyalut adalah $1: 4$. Minyak ikan sebanyak $25 \%$ dari berat bahan penyalut (20 gram) dan lesitin kedele $2.5 \%$ dari berat minyak ikan $(0,5$ gram $)$ diaduk selama 15 menit pada suhu $40^{\circ}-50^{\circ} \mathrm{C}$.

Larutan bahan penyalut dan minyak ikan dicampur dan dihomogenisasi selama 10 menit, selanjutnya dikeringkan dengan pengering semprot. Proses pengeringan dengan pengering semprot dilakukan pada tekanan uap 3 bar dan kecepatan putaran 8,6 rpm. Mikrokapsul minyak ikan tersebut mengandung $\mathrm{ME}$ dan protein kasar masing-masing sebesar 3691 Kkal dan 31,50\%. Proses pembuatan mikrokapsul minyak ikan dapat dilihat pada Gambar 1.

Setiap unit kandang percobaan diberi label sesuai dengan masing-masing perlakuan. Penempatan label untuk masing-masing unit dilakukan secara acak (random) yaitu dengan menggunakan potongan-potongan kertas yang ditulis dengan huruf dan angka perlakuan A1-A5, B1-B5, C1-C5 dan D1-D5, kemudian potongan kertas tersebut diambil secara acak.

DOC broiler juga ditempatkan secara acak disetiap unit kandang. Sebelum DOC ditempatkan dimasing-masing unit perlakuan, dilakukan penimbangan terlebih dahulu untuk menentukan bobot awalnya. Ransum diberikan secara ad-libitum, yang pemberiannya dilakukan $2 \mathrm{x}$ sehari yaitu pagi (jam 08.00 WIB) dan sore (jam 16.00 WIB), sedangkan air minum juga diberikan secara ad-libitum. Hari ke-1 sampai hari ke-4 pakan yang diberikan adalah ransum komersial 511 Bravo.

Pada hari ke-5 mulai dilakukan adaptasi ransum perlakuan dengan cara mencampur $25 \%$ ransum perlakuan dengan $75 \%$ ransum komersial. Pada hari ke-6 pakan yang diberikan adalah campuran $50 \%$ ransum perlakuan dengan $50 \%$ ransum komersial, sedangkan pada hari ke7 dengan perbandingan $75 \%$ ransum perlakuan dan $25 \%$ ransum komersial. Pada hari ke-8 sampai waktu panen (28 hari), pakan yang diberikan adalah $100 \%$ ransum perlakuan.

\section{HASIL DAN PEMBAHASAN}




\section{Lemak Abdomen}

Menurut Kubena et al., (1974), lemak abdomen merupakan lemak yang terdapat disekeliling gizzard dan yang berada diantara otot perut dan usus. Penimbunan lemak pada daerah perut ternak unggas merupakan limbah dalam industri ayam pedaging dan menjadi sumber kontaminasi pada waktu pemrosesan.

Rataan persentase lemak abdomen broiler umur 4 minggu dengan pemberian mikrokapsul minyak ikan ke dalam ransum untuk perlakuan R1, R2, R3 dan R4 adalah $0,80 \%, 0,87 \%, 0,97 \%$ dan $0,94 \%$, seperti terlihat pada gambar 6 .

Gambar 6. Grafik rataan persentase lemak abdomen (\%) / R1 R2 R3 R4 Keterangan : Berbeda tidak nyata $(\mathrm{P}>0,05)$.

Dari data terlihat bahwa rataan persentase lemak abdomen broiler yang terendah diperoleh dari perlakuan R1 (kontrol), yaitu sebesar $0,80 \%$, sedangkan rataan persentase lemak abdomen yang tertinggi pada perlakuan R3, yaitu sebesar $0,97 \%$ dimana pemberian mikrokapsul minyak ikan ke dalam ransum sebanyak 4\%. Berdasarkan hasil analisis ragam, terlihat bahwa pemberian mikrokapsul minyak ikan sampai taraf $6 \%$ ke dalam ransum broiler menunjukkan pengaruh berbeda tidak nyata $(\mathrm{P}>0,05)$ terhadap persentase lemak abdomen.

Hal ini sejalan dengan penelitian yang dilakukan Rusmana dkk (2010) yang menggunakan beberapa level minyak ikan lemuru dan suplementasi vitamin E dalam ransum ayam broiler, yang hasilnya menunjukkan bahwa masing-masing perlakuan baik faktor tingkat penggunaan minyak ikan maupun faktor suplementasi vitamin $\mathrm{E}$, tidak menunjukkan perbedaan yang nyata $(\mathrm{P}>0,05)$ terhadap persentase karkas maupun lemak abdominal. Pada penelitian yang lain, hal yang sama juga dilaporkan oleh Hasanah (2002), dimana pemberian ransum yang menggunakan silase ikan-tape ubi kayu hingga taraf $30 \%$ tidak menunjukkan perbedaan yang nyata $(\mathrm{P}>0,05)$ terhadap persentase lemak abdominal ayam broiler.

Lesson dan Summers (1980) menyatakan bahwa, persentase lemak abdomen ayam broiler umur lima minggu berkisar antara 1,5 - 3,1\% bobot hidup, sedangkan pada penelitian ini persentase lemak abdomen broiler yang diperoleh sedikit lebih rendah, yaitu berkisar antara $0,80-0,97 \%$ untuk umur empat minggu. Sementara itu, penelitian yang dilakukan oleh Hasanah (2002) menggunakan ransum silase ikan-tape ubi kayu juga memberikan hasil yang tidak jauh berbeda, yaitu berkisar antara $0,85-1,12 \%$ untuk ayam broiler umur enam minggu.

Salah satu faktor yang menyebabkan persentase lemak abdomen pada penelitian ini lebih rendah, mungkin disebabkan oleh kondisi umur yang masih muda, dimana keberadaan lemak abdomen belum terlalu banyak terbentuk karena zat-zat makanan yang diserap oleh tubuh ayam masih digunakan untuk pertumbuhan murni. Hal ini sejalan dengan pendapat Dalton dan Lott (1985) yang menyatakan bahwa, persentase lemak abdomen meningkat dengan bertambahnya umur dan tingkat energi ransum. Pembentukan lemak abdomen pada ayam terjadi karena adanya kelebihan energi yang dikonsumsi. Energi yang digunakan oleh tubuh umumnya berasal dari karbohidrat dan cadangan lemak. Disamping itu, persentase lemak abdomen juga dipengaruhi oleh perbedaan jenis kelamin. Kubena dkk., (1974) menyatakan bahwa sumber karbohidrat dalam tubuh mampu memproduksi lemak 
tubuh yang disimpan di sekeliling jeroan dan di bawah kulit.

\section{Kadar Kolesterol}

Kolesterol merupakan salah satu lipoprotein yang berpengaruh terhadap kesehatan konsumen. Rose (1997) menyatakan bahwa daging unggas yang rendah kandungan kolesterolnya lebih menguntungkan bagi kesehatan manusia.

Rataan kolesterol daging ayam broiler umur 4 minggu dengan pemberian mikrokapsul minyak ikan ke dalam ransum untuk perlakuan R1, R2, R3 dan R4 adalah $26,80 \mathrm{mg} / 100 \mathrm{~g}, 9,54 \mathrm{mg} / 100 \mathrm{~g}, 7,00$ $\mathrm{mg} / 100 \mathrm{~g}$ dan $15,12 \mathrm{mg} / 100 \mathrm{~g}$, seperti terlihat pada gambar 7. Gambar 7. Grafik rataan kandungan kolesterol daging (mg/dl) / R1a R2b R3b R4b Keterangan : Super skrip dengan huruf kecil yang tidak sama menunjukkan perbedaan yang nyata $(\mathrm{P}<0,05)$.

Dari data terlihat bahwa rataan kolesterol daging ayam broiler yang terendah diperoleh dari perlakuan R3, yaitu sebesar 7,00 mg/100 g, dimana pemberian mikrokapsul minyak ikan ke dalam ransum sebesar 4\%, sedangkan rataan kolesterol daging yang tertinggi pada perlakuan R1 (kontrol), yaitu sebesar $26,80 \mathrm{mg} / 100 \mathrm{~g}$. Berdasarkan hasil analisis ragam, terlihat bahwa rataan kandungan kolesterol daging perlakuan R2 dan R3 menunjukkan pengaruh berbeda sangat nyata $(\mathrm{P}<0,01)$ lebih rendah dari perlakuan R1 (kontrol), dan perlakuan R4 menunjukkan perbedaan yang nyata $(\mathrm{P}<0,05)$ lebih rendah dibandingkan perlakuan R1 (kontrol), sedangkan antara perlakuan R2, R3 dan R4 menunjukkan pengaruh berbeda tidak nyata $(\mathrm{P}>0,05)$.

Rendahnya kolesterol daging pada ayam yang mengkonsumsi mikrokapsul minyak ikan dibandingkan dengan kontrol (ransum dengan minyak ikan tanpa enkapsulasi) disebabkan oleh ransum dengan pemberian mikrokapsul mampu mencegah oksidasi dari minyak ikan dan mempertahankan kandungan asam lemak omega-3 dengan baik dibandingkan dengan pemberian minyak ikan secara langsung. Tingginya asam lemak omega-3 (EPA dan DHA) dalam ransum berpengaruh terhadap konsentrasi kolesterol.

Griffin (1992) menyatakan bahwa salah satu fungsi omega-3 adalah menghambat biosintesis kolesterol. Diet yang kaya asam lemak tidak jenuh jamak (PUFA) akan menurunkan kadar kolesterol terutama bila diadakan subtitusi asam lemak jenuh dengan asam lemak tidak jenuh. Piliang dan Djojosoebagio (2006) juga menyatakan bahwa, asam lemak omega-3 berperan dalam pengaturan metabolisme kolesterol yang meliputi transport dan ekskresi kolesterol.

Patrick dan Schaible (1980) menyatakan bahwa, asam lemak jenuh sangat cepat terabsorbsi oleh alat pencernaan dan ekskresi kolesterol sangat kecil, sebaliknya asam lemak omega-3 (tidak jenuh) dalam minyak ikan akan menghambat terjadinya biosintesis kolesterol serta menurunkan trigliserida dan VLDL kolesterol dalam plasma darah. Ditambahkan oleh Leskanich dan Noble (1997), asam lemak omega-3 berpengaruh terhadap penurunan VLDL plasma, menurunkan gejala Hiperlipaemia, meningkatkan proses pembekuan darah, menurunkan tekanan darah sistolik dan diastolik serta menurunkan ateriosklerosis dan menurunkan resiko terkena penyakit jantung.

Untuk melihat kandungan asam lemak jenuh, tidak jenuh, omega-3 dan omega-6 dalam daging ayam broiler pada penelitian ini disajikan selengkapnya pada tabel 3 dan 4. Tabel 3. Kandungan asam lemak 
jenuh dan tidak jenuh dalam daging (\%) Perlakuan_Asam Lemak Jenuh_Asam Lemak Tidak Jenuh __RA _ 38,89_61,11 __RB_43,45_56,55__RC_40,18 _59,82__RD_38,10_61,90 _Keterangan : Tidak dilakukan Analisis Ragam Tabel 4.

Kandungan asam lemak ?-6 dan asam lemak ?-3 pada daging (\%) Perlakuan_S?6 _?3_S?-3 _?-6 : ?-3 _ _ _ _Linolenat _EPA_DHA _ _ _RA _ $20,80 \_0,62$ _0,93_1,40_2,95_7,06:1__RB _20,76 _0,59_0,56_1,08_2,23_9,30:1__RC _26,56_0,65_0,91_1,52_3,08_8,61:1 _ _RD_28,21_1,48_1, 17_1,23_3,87 _ 7,28:1__Keterangan : Tidak dilakukan Analisis Ragam EPA = Eicosapentanoic Acid, DHA : Docosahexanoic Acid S?-6 = total asam lemak ?-6 S?-3 = total asam lemak ?-3 (jumlah linolenat, EPA dan DHA)

Secara angka-angka terlihat bahwa semakin tinggi taraf pemberian mikrokapsul minyak ikan (R2 - R4), maka cenderung terjadi kenaikan kandungan asam lemak omega-3 di dalam daging ayam broiler. Hal ini disebabkan karena minyak ikan merupakan sumber asam lemak omega-3.

Asam lemak omega-3 dalam ransum dan daging ayam yang tinggi mempengaruhi komposisi asam lemak tak jenuh lainnya. Komposisi asam lemak tak jenuh selain dari asam lemak omega-3 yang dapat dideteksi adalah asam linoleat, asam oleat, palmitoleat, aracidonat, EPA dan DHA. Dibandingkan dengan perlakuan R1 (kontrol), perlakuan R2 mengandung asam lemak omega-3 yang lebih rendah, hal ini mungkin disebabkan karena pada ransum 2 mengandung minyak kelapa yang merupakan sumber asam lemak jenuh, sedangkan ransum 1 (kontrol) tidak menggunakan minyak kelapa sama sekali.
Pada perlakuan R3 dan R4 terjadi peningkatan kandungan asam lemak omega-3 seiring dengan meningkatnya kadar mikrokapsul minyak ikan dalam ransum, dan kadar minyak kelapa yang semakin rendah (Tabel 2). Pemberian mikrokapsul minyak ikan dalam ransum juga menurunkan imbangan asam lemak omega-6 dibanding omega-3 pada daging ayam broiler.

Hal yang serupa juga terjadi pada penelitian (Montesqrit dan Adrizal, 2009), dimana pemberian mikrokapsul minyak ikan dalam ransum ayam petelur menurunkan imbangan asam lemak omega-6 dibanding omega-3 pada kuning telur dari 14:1 pada kontrol menjadi 4,7 5,4:1 setelah pemberian 4\% MMI. Rasio perbandingan omega- 6 dan omega- 3 yang ideal adalah apabila dapat mendekati 5:1 (Farrel, 1996).

Rasio ini memberikan hasil yang lebih baik, hal ini berkaitan dengan sinergisme pada pembentukan misel sehingga lebih mudah diabsorbsi (Leeson dan Atteh, 1995). Peningkatan omega-3 ini sesuai dengan penelitian Marshal et al., (1994) yang disitasi oleh Leskanich dan Noble (1997) bahwa ransum yang menggunakan $1,5 \%$ minyak menhaden dapat meningkatkan omega-3 dibanding ransum kontrol.

Asam linoleat (omega-6) pada telur semakin menurun seiring meningkatnya kandungan omega-3, hal ini diduga tingginya omega-3 akan menghambat sintesis omega-6, sesuai dengan pendapat Murray et al., (1995) bahwa biosintesis omega-3 akan menghambat biosintesis omega-6 dengan cara berkompetisi untuk sistem enzim yang sama. Mengkonsumsi makanan yang mempunyai imbangan asam lemak omega-6 : omega-3 yang tinggi dapat berpengaruh buruk terhadap kesehatan. Menurut Okuyama et al., 
(1997) imbangan asam lemak omega-6 dan omega-3 yang tinggi dalam makanan yang dikonsumsi manusia merupakan faktor utama penyakit kanker kardiovaskuler dan serebrovaskuler.

Produk ternak unggas dalam hal ini daging yang tinggi kandungan asam lemak omega-3 dapat mempengaruhi nilai jual dan minat beli konsumen untuk mengkonsumsinya. Banyak manfaat dari mengkonsumsi daging ini, terutama dalam meningkatkan kecerdasan dan juga dapat menurunkan kolesterol jika dibandingkan dengan mengkonsumsi daging-daging ternak unggas yang sudah umum beredar dipasaran yang rendah kandungan asam lemak omega-3nya. Kandungan lemak berkorelasi positif dengan kolesterol daging, sehingga semakin tinggi kandungan lemak daging unggas, semakin tinggi pula kandungan kolesterolnya (Hargis dan Creger, 1980).

\section{KESIMPULAN DAN SARAN}

Berdasarkan hasil penelitian dapat disimpulkan bahwa penggunaan MMI (mikrokapsul minyak ikan) taraf 2\% dalam ransum ayam broiler dapat memberikan pengaruh berbeda nyata terhadap kandungan kolesterol daging dibandingkan kontrol (minyak ikan yang tidak dilindungi), sedangkan untuk persentase lemak abdomen memberikan pengaruh berbeda tidak nyata hingga pemakaian MMI taraf 6\%.

Kandungan kolesterol daging terendah $(7,00 \mathrm{mg} / \mathrm{dl})$ diperoleh pada pemberian MMI sebesar 4\%. Saran Dari hasil penelitian ini dapat disarankan untuk menggunakan $2 \%$ MMI pada ransum ayam broiler (sebagai feed Supplement), dan perlu adanya pihak ketiga yang memproduksi mikrokapsul minyak ikan secara komersial agar ketersediaan mikrokapsul minyak ikan dapat terjaga sekaligus dapat menekan biaya pembuatan jika dibandingkan dengan memproduksi dalam skala kecil.

\section{DAFTAR PUSTAKA}

[NRC] National Research Council, 1994. Nutrient Requirements of Poultry. Ed ke-9. Washington DC: National Academy Pr Baucells MD. Crespo N. Barroeta SC. Lopez-Ferrer S. Grashorn MA. 2000. Incorporation of different polyunsaturated fatty acids into eggs. Poultry Sci 79:51-59.

AAK, 1982. Pedoman Beternak Ayam Negeri. Kanisius. Yogyakarta.

Amrullah, I.K. 2003. Nutrisi Ayam Petelur. Penerbit Lembaga Satu Gunung Budi. Bogor.

Anggorodi, R. 1991. Ilmu Makanan Ternak Umum. PT. Gramedia Pustaka Utama. Jakarta.

Bakan, J.A. 1986. Mikroenkapsulasi Teori dan Praktek Farmasi Industri. UIPress. Jakarta.

Bartkowiak, A. 2001. Caragenanoligochitosan Microcapsules: Optimization of the Formation Process. Journal of Biointerfaces 2001; 21; 285-298.

Brake, J.G.B., \& S.E. Havenstein. 1993. Relationship of Sex. Age and Body Weight to Broiler Carcass Yield and Offal Production. Poultry Sci. 72: 1137-1145.

Card, L. E. and M. C. Nesheim. 1972. Poultry Production. 11th Ed. Lea and Febiger. Philadelphia. California.

Cerdeira, M. Palazolo. G.G. Candal. R.J. and Herera. M.L. 2007. Factors 
Affecting Initial Retention of a Microencapsulated Sunflower Seed Oil/Milk Fat Fraction Blend. J Am. Oil Chem Soc 84: 523-531.

Fadilah, R. 2004. Ayam Broiler Komersial. Agromedia Pustaka. Jakarta.

Fadilah, R. 2005. Panduan Mengelola Peternakan Ayam Broiler Komersial. Agromedia Pusaka. Jakarta.

Farrel, D.J. 1996. The heart smart egg : Why it is good for you. Makalah pada Seminar Internasional WPSA September 1996, Undip Semarang.

Garg, ML. Wood LG. Singh $\mathrm{H}$ and Moughan PJ. 2006. Means of Delivering Recommended Levels of Long Chain n-3 Polyunsaturated Fatty Acids in Human Diets. J Food Sci 71(5):R66.

Grifin, H.D. 1992. Control of Egg Yolk Cholesterol. Proceedings of The 5th European Symposium on The Quality of Eggs and Egg Products. held at the "Vinci" Congress Centre In Tours : $378-383$.

Hargis, P.U. and C.R. Creger. 1980. Effect of Varying Dietary Protein and Energy Levels on Abdominal Fat Pad Development of the Broiler Chicken. Poultry Sci. 61 (59): 1499-1504.

Hasanah, S. 2002. Pengaruh Pemberian Silase Ikan-Tape Ubi Kayu Terhadap Persentase Berat Karkas, Lemak Abdomen dan Orgam Dalam Ayam Broiler. Skripsi. Fakultas Peternakan IPB, Bogor.

Howe, PRC. Downing JA. Grenyer BFS. Grigonis-Deane EM. and Bryden WL. 2002. Tuna Fishmeal as Source of DHA for n-3 PUFA Enrichment of
Pork. Chicken and Eggs. Lipids 37: 1067-1076.

Huang, ZB. Leibovitz H. Lee CM. Millar R. 1990. Effect of dietary fish oil on omega-3 fatty acid levels in chicken eggs and thigh flesh. J Agric Food Chem 38:743-747.

Kartasudjana, R dan Edjeng S. 2006. Manajemen Ternak Unggas. Penebar Swadaya. Jakarta.

Kim, Y.D. dan Moor. 1996. Microencapsulation Properties of Gum Arabic and Several Protein: Spray Dried Orange Oil Emultion Particles. J. Agric. Food Chem. 44;1308-1313.

Kubena, L.F., J.W. Deaton. T.C. Chen and F.N. Reece. 1974. Factors Influencing the Quality of Abdominal Fat in Broiler. Poultry Sci. 53:211-214.

Langdon, C.J. Levine. D.M. and Jones. D.A. 1985. Microparticulated feeds for marine suspension-feeders. J Microencapsulation 2:1-11.

Leskanich, C.O. and R.C. Noble. 1997. Manipulation of the n-3 Polyunsaturated Fatty Acid Composition of Avian Eggs and Meat. World's Poultry Journal 53:155-183.

Lesson, S and Summers. 1980. Production and Carcas Characteristic of the Broiler Chicken. Poultry Sci. 59:786798.

Leeson, S., and J. O Atteh. 1995. Utilization of fats and fatty acids by Turkey poults. Poultry Sci. 74 : 2003 2010.

Montesqrit, 2007. Penggunaan Bahan Baku Pakan Sebagai Bahan Penyalut dalam Mikroenkapsulasi Minyak Ikan 
Lemuru dan Pemanfaatannya dalam Ransum Ayam Petelur. Disertasi. Program Pascasarjana IPB. Bogor.

Montesqrit, dan Adrizal. 2009. Optimasi Produksi Mikrokapsul Minyak Ikan Sebagai Feed Aditif untuk Menghasilkan Produk Unggas Kaya Asam Lemak Omega-3 dan Rendah Kolesterol. Laporan Penelitian Hibah Bersaing. Universitas Andalas. Padang.

Murray, R. K., D. K. Ganner, P. A. Mayes and V. W. Rodwell. 1995. Biokimia Harper. EGC, Jakarta.

Murtidjo, B.A. 1990. Pedoman Meramu Pakan Unggas. Kanisius. Yogyakarta.

Murtidjo, B.A. 1992. Pedoman Beternak Ayam Broiler. Kanisius. Yogyakarta.

North, M.O. and D.D. Bell. 1990. Commercial Chicken Product Manual. 4th Ed. Van Nostrand Reinhold. New York.

Okuyama, H., Kobayashi T, Watanabe S. 1997. Dietary fatty acids - the n-6/n balance and chronic elderly diseases excess linoleic acid and relative n-3 deficiency syndrome seen in Japan. Progress in Lipid Res 35:409-457.

Piliang, W.G., Djojosoebagio. S.A. 2006. Fisiologi Nutrisi. Volume ke-1. IPB Press. Bogor.

Rasyaf, M. 2004. Beternak Ayam Pedaging. Penebar Swadaya. Jakarta.

Rizal, Y. 2006. Ilmu Nutrien Unggas. Andalas University Press. Padang

Rose, S.P. 1997. Priciples of Poultry Science. CAB. International. WallingFord. USA.
Rusmana, D. 2008. Minyak Ikan Lemuru sebagai Imunomodulator dan Penambahan Vitamin E untuk Meningkatkan Kekebalan Tubuh Ayam Broiler. Disertasi. Program Pascasarjana IPB. Bogor.

Rusmana, D. 2010. Pengaruh Subtitusi Minyak Sawit oleh Minyak Ikan Lemuru dan Suplementasi Vitamin E Dalam Ransum Ayam Broiler Terhadap Performans. http://pustaka.unpad.ac.id/wpcontent/uploads/2010/10/ pengaruh_ransum_mengandung_miny ak_ikan_lemuru_thdp_bobot_bdh_akh ir.pdf. [17-04-2012].

Rusmana, D., D. Natawiharja. dan Lalah. L.S. 2010. Pengaruh Ransum Mengandung Minyak Ikan Lemuru dan Suplementasi Vitamin E Terhadap Bobot Badan Akhir. Persentase Karkas Dan Lemak Abdominal Ayam Broiler. http://pustaka.unpad.ac.id/wpcontent/uploads/2010/10/

pengaruh_ransum_mengandung_miny ak_ikan_lemuru_thdp_bobot_bdh_akh ir.pdf [17-04-2012].

Setiabudi, E. 1990. Pengaruh Waktu Penyimpanan dan Jenis Filter pada Jumlah Asam Lemak Omega-3 dalam Minyak Limbah Hasil Pengalengan dan Penepungan Ikan Lemuru. Tesis. Program Pascasarjana IPB. Bogor.

Shahidi, F. and Han X.Q. 1993. Encapsulation of Food Ingredients. Crit Rev Food Sci Nutr 33:501-547.

Siregar, A.P.M. Sabrani dan P. Suroprawiro. 1980. Teknik Beternak Ayam Pedaging di Indonesia. Cetakan ke-I. Margie Group. Jakarta. 
Soeparno, 2005. Ilmu dan Teknologi Daging. Gadjah Mada University Press. Yogyakarta.

Steel, R.G.D. dan J.H. Torrie. 1995. Prinsip dan Prosedur Statistika Suatu Pendekatan Biometrik. Cetakan Ke 2. (Alihbahasa. Sumantri. B). Penerbit PT. Gramedia. Jakarta.

Supadmo, 1997. Pengaruh Sumber Khitin dan Prekursor Karnitin serta Minyak Ikan Lemuru terhadap Kadar Lemak dan Kolesterol serta Asam Lemak Omega-3 Ayam Broiler. Disertasi. Program Pascasarjana IPB. Bogor.

Suprijatna, E., U. Atmomarsono dan R. Kartasudjana. 2005. Ilmu Dasar Ternak Unggas. Penebar Swadaya, Jakarta.

Thies, C. 1996. A Survey of Microencapsulation Process and Aplication. Plenum Press. New York.

Tillman, D.A., Hartadi. H., Reksohadiprodjo. S., Lebdosoekojo. S. 1991. Ilmu Makanan Ternak Dasar. Gadjah Mada University Press. Fakultas Peternakan UGM. Yogyakarta.

Wahyu, J. 1997. Ilmu Nutrisi Unggas. Gadjah Mada University Press. Yogyakarta.

Wander, R.C. Hall. J.A. Gradin. J.L. Du. S.H. \& Jewell. D.E. 1997. The Ratio of Dietary (n-6) to (n-3) Fatty Acids Influences Immune System Function. Eicosanoid Metabolism. Lipid Peroxidation and Vitamin E Status in Aged Dogs. J Nutr 127. 1198-1205. Department of Nutrition and Food Management. Oregon State University. USA.
Yusniar, L. dan E. Nilasari. 2007. Biar Daging Ayam Tak Berkolesterol Tinggi. http://www.majalahtrust.com/bisnis/p eluang/284.php [04-06-2011]. 